\title{
KARAKTERISTIK EMULSI BEBERAPA FRAKSI GELATIN DARI KULIT IKAN NILA (Oreochromis niloticus)
}

\section{The Emulsion Characteristic of Gelatin Fraction from Tilapia (Oreochromis niloticus) Skin}

\author{
Suryanti ${ }^{*}$, Djagal Wiseso Marseno ${ }^{2}$, Retno Indrati ${ }^{2}$, dan Hari Eko Irianto ${ }^{1}$ \\ ${ }^{1}$ Balai Besar Riset Pengolahan Produk dan Bioteknologi Kelautan dan Perikanan. \\ JI. KS. Tubun, Petamburan VI, Slipi, Jakarta, Indonesia \\ ${ }^{2}$ Fakultas Teknologi Pertanian. Universitas Gajah Mada. JI. Flora No. 1 \\ Bulaksumur. Yogyakarta, Indonesia \\ *Korespondensi Penulis: suryanti_jkt@yahoo.com
}

Diterima: 25 Januari 2017; Disetujui: 29 April 2017

\begin{abstract}
ABSTRAK
Fraksinasi ekstrak gelatin dari kulit ikan nila (Oreochromis niloticus) dengan menggunakan kantong dialisis MWCO $100 \mathrm{kD}$ telah dilakukan. Penelitian ini bertujuan untuk mengetahui karakteristik emulsi dari fraksi gelatin yang diperoleh melalui proses asam asetat $0,10 \mathrm{M}$ (GAs) dan asam sitrat 0,05 M (GSi). Fraksi gelatin GAs yang diperoleh memiliki distribusi berat molekul 13,6-218,87 kD dan 15,27-61,1 kD sedangkan fraksi gelatin GSi sebesar 107,5-142,23 kD dan $12,5-82,9$ kD. Gugus fungsional molekul dari keempat fraksi gelatin tersebut terdiri dari amida I $\left(1648 \mathrm{~cm}^{-1}\right)$, amida II $\left(1452 \mathrm{~cm}^{-1}\right)$ dan amida III $\left(1089 \mathrm{~cm}^{-1}\right)$. Karakteristik emulsi yang meliputi sifat emulsi (aktivitas dan stabilitas emulsi) serta ukuran partikel emulsi semakin meningkat dengan semakin meningkatnya berat molekul. Zeta potensial droplet emulsi gelatin dari proses asam sitrat $0,05 \mathrm{M}$ (GSi) lebih banyak bermuatan ion positif daripada proses asam asetat 0,10 M(GAs). Emulsi yang terbentuk dari fraksi GAs dan GSi pada konsentrasi $0,1 \%$ termasuk dalam makroemulsi dengan ukuran droplet $>100 \mathrm{~nm}$ dan stabilitas mencapai 22,62 menit yang dapat diaplikasikan pada produk pangan seperti ice cream, whipping cream, dan salad dressing.
\end{abstract}

KATAKUNCI : ikan nila, Oreochromis niloticus, emulsi, gelatin

\section{ABSTRACT}

Fractionation of gelatin extract from tilapia (Oreochromis niloticus) skin was done by using dialysis bag of MWCO $100 \mathrm{kD}$. The aim of this research was to determine the emulsion characteristics of gelatin fraction from the process of $0.10 \mathrm{M}$ acetic acid (GAs) and $0.05 \mathrm{M}$ citric acid (GSi). Gelatin GAs fraction has a molecular weight distribution of 13.6 to $218.87 \mathrm{kD}$ and 15.27 to $61.1 \mathrm{kD}$ while gelatin GSI fraction of 107.5 to $142.23 \mathrm{kD}$ and 12.5 to $82.9 \mathrm{kD}$. Functional groups of the four fractions of gelatin molecules consist of amide I $\left(1648 \mathrm{~cm}^{-1}\right)$, amide II $\left(1452 \mathrm{~cm}^{-1}\right)$ and amide III $(1089 \mathrm{~cm}$ $\left.{ }^{1}\right)$. Emulsion characteristics including the emulsion properties (activity and stability of emulsion) and particle size emulsion increased with the increasing of molecular weight. Zeta potential of emulsion droplet gelatin from 0.05M citric acid (GSi) method produced more positively charged ions than $0.10 \mathrm{M}$ acetic acid process (GAs). Emulsion created by $0,1 \%$ GAs and GSi fraction was refer to macroemulsion with droplet size $>100 \mathrm{~nm}$ and stability 22.62 minutes, which could be applied for food product such as ice cream, whipping cream and salad dressing..

KEYWORDS: tilapia, Oreochromis niloticus, emulsion, gelatin

\section{PENDAHULUAN}

Gelatin merupakan hasil dari proses hidrolisis kolagen yang banyak ditemukan pada kulit, tulang dan jaringan otot hewan. Gelatin diperoleh melalui proses pra-perlakuan asam (gelatin tipe A) dengan nilai titik isoelektrik pada $\mathrm{pH}$ 7-9 atau basa (gelatin tipe $\mathrm{B})$ dengan nilai titik isoelektrik pada $\mathrm{pH} 4,7-5,4$ (Anon, 2012). Umumnya, gelatin yang berasal dari kulit ikan diperoleh melalui proses pra-perlakuan asam karena jaringan kolagen pada kulit ikan lebih lunak. Perlakuan asam menyebabkan terlepasnya ikatan antara gugus karboksil dan gugus amida dalam molekul kolagen triple helix hingga terpecah menjadi 
beberapa untaian rantai $\alpha$-helix dan diperoleh berat molekul gelatin dalam kisaran yang luas yaitu 90-300 kD (Phillip \& Williams, 2009).

Gelatin banyak digunakan dalam industri pangan, farmasi dan medis karena memiliki sifat fungsional sebagai pembentuk gel, pengental dan emulsifier. Namun penggunaan gelatin sebagai emulsifier masih terbatas karena berat molekul yang besar dapat menghasilkan ukuran partikel droplet emulsi yang besar (Surh, Decker, \& Mc Clement, 2006). Beberapa produk pangan umumnya membutuhkan emulsifier yang dapat menghasilkan ukuran partikel droplet emulsi yang kecil sehingga penampakan emulsi menjadi lebih jernih.

Emulsi adalah suatu dispersi dua cairan (minyak dan air) yang tidak dapat tercampur, dimana salah satu cairan terdispersi di dalam cairan lainnya sebagai droplet kecil dengan ukuran berkisar antara 0,1-100 ìm (Mc Clement, 2005). Kondisi ini membutuhkan bahan pembentuk dan penstabil emulsi (emulsifier) yang dapat menyerap fase minyak dan air yang dapat melindungi droplet dari kerusakan (Hasenhuetl \& Hartel, 2008). Gelatin memiliki kemampuan sebagai emulsifier karena bersifat amphiphilic dengan adanya kandungan asam amino yang bersifat hidrofilik dan lipofilik sehingga dapat menimbulkan aktifitas pada permukaan molekulnya (Ward \& Courts, 1977). Muatan dalam molekul gelatin menyebabkan gelatin dapat terserap pada antarmuka fase minyak dan air dalam sistem emulsi, dan membentuk jaringan polimer berupa lapisan (film) pada permukaan droplet (Hattrem, Molnes, Haug, \& Draget, 2015).

Gelatin dengan kisaran distribusi berat molekul yang luas terdiri dari komponen sub unit $\alpha, \beta$ dan $\gamma$. Sub unit $\beta$ merupakan dimer dari sub unit $\alpha$, sedangkan sub unit y merupakan trimer sub unit $\alpha$ (Ward \& Coutrs, 1977). Sub unit a mengandung beberapa jenis asam amino yang berbeda sehingga sangat berpengaruh pada sifat fungsional gelatin. Gelatin dengan berat molekul besar memiliki sub unit a yang lebih banyak dapat menghasilkan sifat fungsional seperti kekuatan gel yang lebih besar.

Pemisahan sub unit $\alpha$ dalam molekul gelatin dapat dilakukan berdasarkan ukuran berat molekul menggunakan membran dialisis dengan tujuan fraksinasi yaitu untuk memisahkan dua fraksi komponen yang diinginkan. Membran dialisis komersial umumnya berasal dari selulosa yang merupakan polisakarida yang berasal dari tumbuhan yang tersusun dari beberapa unit glukosa yang terhubung dalam ikatan $\beta-1,4$ glukosa. Struktur rantai linear selulosa merupakan polimer yang bersifat hidrofilik karena terbentuk dari ikatan hidrogen intramolekular diantara grup hidroksil yang terdapat pada molekul glukosa, sehingga dapat menyerap protein larut air dan melewati membran. Pada pemisahan ekstrak protein dengan membran dialisis akan terpisah fraksi makromolekul yang akan tertahan didalam kantong dialisis dan mikromolekul akan keluar dari kantong dialisis sehingga diperoleh fraksi berat molekul yang berbeda (Mulder, 1996).

Fraksinasi gelatin dari kulit ikan Saithe (P. virens) dapat dilakukan menggunakan membran dialisis dengan molecule weight cut off (MWCO) $100 \mathrm{kD}$ dalam larutan MILLI-Q water pada suhu $40^{\circ} \mathrm{C}$ (Eysturskars, Haug, Elharfaoui, Djabourov, \& Drage, 2009). Gelatin dengan kandungan sub unit a yang besar dapat menghasilkan sifat fungsional pembentukan gel serta aktivitas dan stabilitas emulsi yang tinggi (Ahmad \& Benjakul, 2011 ; Eysturskaro, et.al., 2009). Surh et.al., (2006) menyatakan gelatin tipe A dapat menjadi alternatif sebagai emulsifier dari protein dalam sistem emulsi minyak dalam air karena dapat membentuk droplet bermuatan kationik pada kisaran $\mathrm{pH}$ yang lebih luas. Muatan kation pada permukaan droplet dapat mencegah oksidasi minyak dalam droplet dengan adanya kation mineral seperti $\mathrm{Fe}^{2+}$ atau $\mathrm{Fe}^{3+}$ yang umumnya terdapat dalam fase air.

Isolasi gelatin dari kulit ikan nila (Oreochromis niloticus) dari pra-perlakuan asam asetat $0.10 \mathrm{M}$ dan asam sitrat 0,05 $\mathrm{M}$ menghasilkan distribusi berat molekul sebesar 38-241 kD dan 23-145 kD dengan kandungan sub unit $\alpha$ yang berbeda menghasilkan kekuatan gel 346,16 g bloom dan 13,52 g bloom (Suryanti, Indrati, Irianto, \& Marseno, 2016). Gelatin ikan tipe $A$ dengan berat molekul $\approx 55 \mathrm{kD}$ dan $\approx 120$ $\mathrm{kD}$ menghasilkan ukuran rata-rata diameter droplet emulsi sebesar $0.35 \mu \mathrm{m}$ dan $0.71 \mu \mathrm{m}$ (Surh et al., 2006). Selain itu, gelatin dari kulit babi dengan berat molekul 50-100 kDa menghasilkan stabilitas emulsi yang baik pada $\mathrm{pH} 4,8$ dalam sistem emulsi minyak dalam air (Liu, Wang, Barrow, \& Adhikari, 2014). Hal ini menunjukkan berat molekul gelatin dengan kandungan sub unit a yang berbeda memiliki kemampuan sebagai emulsifier. Dalam penelitian ini dilakukan fraksinasi gelatin dari kulit ikan nila $(O$. niloticus) terhadap karakteristik emulsi. Tujuan dari penelitian ini adalah untuk mengetahui karakteristik emulsi dari beberapa fraksi berat molekul gelatin dari kulit ikan nila (O. niloticus).

\section{BAHAN DAN METODE}

\section{Bahan}

Bahan utama yang digunakan meliputi kulit ikan nila (O. niloticus) yang diperoleh dari PT. Aquafarm di Semarang Jawa Tengah dan minyak kedelai komersial. Bahan kimia yang digunakan meliputi 
asam asetat (teknis), asam sitrat (teknis), akrilamid, N'N'N'Bis-Akrilamid, glycine (Sigma Chemical Co.), protein leader (10-260 kD) (Thermo Scientific), HCl, $\mathrm{NaOH}$, Tetramethylethylenediamine (TEMED) (Thermo Scientific), ultra tris-base, ammonium persulfate, Coomassie brilliant blue R250 (Sigma Chemical Co.), methanol, asam asetat glasial dan $\mathrm{MQ}$-water.

Peralatan yang digunakan meliputi kantong dialisis (cellulose membrane MWCO 100 kD) (Spectrum Laboratories Inc., DG Breda, Netherlands), pH meter, PAGE (Polyacrylamide gel electrophoresis), viscometer brookfield, UV-Vis spectrophotometer (Shimadzu), Particle Size Analyzer (Delsa Max PRO. Beckman Coulter) dan optical light microscope (Leica ICC50 H).

\section{Metode}

\section{Isolasi dan fraksinasi gelatin dari kulit ikan nila (O. niloticus)}

Isolasi gelatin dari kulit ikan nila 0 . niloticus) dilakukan secara asam melalui pra-perlakuan asam asetat 0,10 M dan asam sitrat 0,05 M (Suryanti et al., 2016). Degreasing dilakukan dengan pencelupan dalam air $\left(60-70^{\circ} \mathrm{C}\right)$ selama \pm 10 detik dan dilanjutkan dengan pengecilan ukuran kulit nila \pm (4 $\mathrm{x}$ $4 \mathrm{~cm})$. Pra-perlakuan dilakukan dengan proses asam asetat $0.10 \mathrm{M}$ selama 2 jam dan asam sitrat $0.05 \mathrm{M}$ selama 1 jam (1:8 (b/v)). Pencucian dalam air bersih hingga $\mathrm{pH}$ mendekati netral dan pengecilan ukuran kulit dengan alat homogenizer ( \pm 10 detik). Ekstraksi menggunakan akuades dengan rasio 1:3 (b/v) pada suhu $80^{\circ} \mathrm{C}$ selama 3 jam hingga diperoleh ekstrak gelatin. Fraksinasi ekstrak gelatin dari perlakuan kedua jenis asam tersebut menggunakan kantong dialisis MWCO 100 kD dalam akuades pada suhu kamar selama 12 jam hingga masing-masing diperoleh dua fraksi dengan berat molekul yang berbeda. Kemudian larutan dialisat yang dihasilkan dipekatkan dengan vacum evaporator pada suhu 40 ${ }^{\circ} \mathrm{C}$ dan dikeringkan dengan konsentrator hingga diperoleh fraksi gelatin kering.

\section{Analisis molekul fraksi gelatin}

Analisis molekul fraksi gelatin yang dilakukan meliputi analisis berat molekul dan anlisis gugus fungsional molekul gelatin. Analisis berat molekul fraksi gelatin menggunakan SDS PAGE (Polyacrylamide gel electrophoresis) berdasarkan metoda yang dikembangkan oleh Biorad Laboratories (2016) menggunakan stacking gel $5 \%$ dan resolving gel $10 \%$ dengan menggunakan marker protein ladder (10-260 kD) (Thermo Scientific) yang dijalankan dalam Elektroforesis pada tegangan $200 \mathrm{~V}$ dan $65 \mathrm{~mA}$.
Pewarnaan gel dengan Coomassie brilliant blue R250 dan penghilangan warna dengan campuran larutan methanol : asam asetat glasial : akuades dengan rasio sebesar 1:1:8 (v/v/v).

Analisis gugus fungsional molekul fraksi gelatin dilakukan dengan menggunakan alat Spectra Fourier transform infrared (FTIR) (Montoya et al., 2013). Sampel fraksi gelatin kering ditambah $\mathrm{KBr}(1: 100)$ dan dihaluskan hingga tercampur merata, kemudian dilakukan pengepresan dengan pompa vakum selama 15 menit. Pembacaan absorbansi dilakukana pada bilangan gelombang $400-4000 \mathrm{~cm}^{-1}$.

\section{Analisis dan karakteristik emulsi}

Analisis dan karakteristik emulsi diawali dengan pembuatan emulsi gelatin berdasarkan Ahmad dan Benjakul (2011) dan Ktari et al. (2014). Gelatin (0,1\%) ditambahkan minyak kedele dengan rasio 3:1(v:v) kemudian dihomogenasi dengan homogenizer ultratorax pada kecepatan 7000 rpm selama 3 menit pada suhu kamar. Karakteristik emulsi gelatin diketahui melalui analisis $\mathrm{pH}$ emulsi, sifat emulsi, ukuran partikel emulsi dan zeta potensial dan mikrostruktur emulsi.

Analisis $\mathrm{pH}$ emulsi dilakukan menggunakan $\mathrm{pH}$ meter pada emulsi yang terbentuk dari beberapa fraksi gelatin pada suhu kamar (Ward \& Courts, 1977 modifikasi).

Analisis sifat emulsi yang dilakukan meliputi Emulsion Activity Index (EAI) dan Emulsion Stability Index (ESI) yang diperhitungkan berdasarkan pada metode yang dikembangkan oleh Pearce dan Kinsella (1978) dan Ahmad dan Benjakul (2011) sebagai berikut.

$$
\begin{aligned}
& \mathrm{EAI}\left(\frac{\mathrm{m} 2}{\mathrm{~g}}\right)=\frac{2 \chi 2,303 \chi \text { Ao } \chi \mathrm{Fp}}{\phi \chi \mathrm{C} \chi \mathrm{I}} \\
& \mathrm{ESI} \text { (menit) }=\frac{\mathrm{Ao}}{\mathrm{Ao}-\mathrm{A} 10} \chi \Delta \mathrm{t}
\end{aligned}
$$


Ukuran partikel droplet emulsi gelatin dan nilai zeta potensial dianalisis berdasarkan metoda Hattrem et al. (2015) yang dimodifikasi. Emulsi gelatin ditambahkan dengan $M Q$ water dengan rasio 1:100 (v/v) pada suhu kamar dan di vortex selama 10 detik. Ukuran partikel droplet emulsi dan zeta potensial diukur dengan alat Particle Size Analyzer (Delsa Max PRO. Beckman Coulter). Pengukuran didasarkan pada intensitas penyebaran cahaya laser terhadap larutan emulsi dan kemudian dapat diketahui distribusi ukuran diameter partikel droplet dan zeta potensial.

Analisis mikrostruktur emulsi dilakukan secara visual menggunakan optical light microscope (Leica ICC50 H) yang dilengkapi dengan kamera dengan perbesaran 40 kali (Gao et al., 2017 yang dimodifikasi).

\section{Analisis data}

Analisis data dilakukan terhadap semua data hasil analisis (kecuali analisis distribusi berat molekul dan mikrostruktur emulsi) disajikan dalam jumlah rata rata dan dianalisis statistik menggunakan one way analysis of variant (ANOVA) dengan tingkat signifikansi 95\% dengan program SPSS 16 for Windows. Uji lanjut Duncan's Multiple Range Test(DMRT) dilakukan untuk mengetahui perbedaan diantara perlakuan.

\section{HASIL DAN BAHASAN}

\section{Distribusi Berat Molekul}

Proses pemisahan molekul dengan membran dialisis didasarkan pada ukuran dan bentuk atau struktur molekul yang tertahan dan melewati membran. Hasil dari proses pemisahan suatu molekul dengan membran akan diperoleh dua fraksi molekul yaitu retentate (yang terdapat dalam membran) dan permeate (yang mengalir keluar melewati membrane) (Mulder, 1996). Gambar 1 dan 2 menyajikan hasil analisis distribusi berat molekul dari fraksinasi ekstrak gelatin kulit ikan nila (Oreochromis niloticus) dari proses asam asetat $0,10 \mathrm{M}$ selama 2 jam (GAs) dan proses asam sitrat $0,05 \mathrm{M}$ selama 1 jam (GSi). Jumlah protein fraksi gelatin GAs yang ditanamkan dalam gel sebesar $120 \mu \mathrm{g}$ sedangkan fraksi gelatin GSi $80 \mu \mathrm{g}$.

Dari Gambar 1 diketahui distribusi berat molekul dari dua fraksi gelatin GAs yaitu fraksi GAs retentate 100 kD sebesar 13,6-140 kD mengandung sub unit a, sedangkan fraksi GAs permeate $100 \mathrm{kD} 15,27$ $61,1 \mathrm{kD}$ tidak ditemukan sub unit $\alpha$. Selain itu, dari Gambar 2 juga diketahui distribusi berat molekul dari fraksi GSi retentate $100 \mathrm{kD}$ sebesar 107,5-142,23 kD dan fraksi GSi permeate 100 kD 12,5 - 82,9 kD. Pada

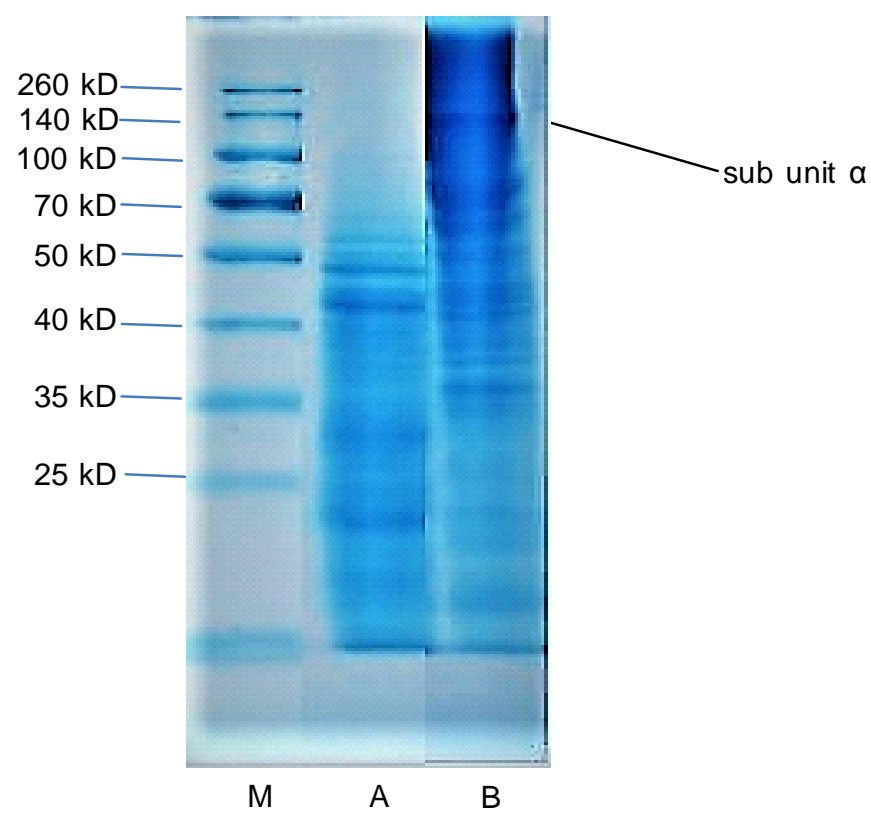

Gambar 1. Distribusi berat molekul fraksi gelatin kulit ikan nila (O. niloticus) dari proses asam asetat 0,10 $\mathrm{M}$ selama 2 jam (GAs). M : marker protein, $A$ : fraksi retentate $100 \mathrm{kD}, \mathrm{B}$ : fraksi permeate 100 $\mathrm{kD}$.

Figure 1. Molecular weight distribution of gelatin tilapia (O. niloticus) skin fraction from $0.10 \mathrm{M}$ acetat acid processed for 2 hours (GAs). $M$ : protein marker, $A$ : retentate $100 \mathrm{kD}$ fraction, $B$ : permeate $100 \mathrm{kD}$ fraction. 
fraksi GSi retentate $100 \mathrm{kD}$ mengandung sub unit $\alpha$, sedangkan fraksi GSi permeate 100 kD tidak ditemukan. Gelatin mengandung sub unit a pada kisaran berat molekul $90-<200 \mathrm{kD}$, sub unit $\beta$ pada berat molekul $200-<270 \mathrm{kD}$ dan sub unit y pada berat molekul 270-300 kD (Phillip \& Williams, 2009). Gelatin dengan kandungan sub unit $\alpha$ yang lebih rendah akan lebih mudah terpisah dalam kantong dialisis. Hal ini terlihat dari hasil proses fraksinasi gelatin GAs belum sempurna terpisah fraksi berat molekulnya karena masih banyak terdapat berat molekul $<100 \mathrm{kD}$ dalam fraksi retentate. Gelatin yang diperoleh dari proses asam sitrat 0,05 $\mathrm{M}$ selama 1 jam (GSi) memiliki distribusi berat molekul 23-145 kD lebih mudah dipisahkan fraksi berat molekul $<100 \mathrm{kD}$ dan $>100$ $\mathrm{kD}$ daripada proses asam asetat $0,10 \mathrm{M}$ selama 2 jam (GAs) yang memiliki distribusi berat molekul 38$241 \mathrm{kD}$ banyak mengandung sub unit $\beta$ (Suryanti et al., 2016).

Pemisahan berat molekul ekstrak gelatin dari kulit ikan haddock (Melanogrammus aeglefinus), saithe (Pollachius virens) dan cod (Gadus morhua) juga telah dilakukan menggunakan membran dialisis MWCO 100 $\mathrm{kD}$ dalam MILLI-Q water pada suhu $40^{\circ} \mathrm{C}$ untuk mengetahui pengaruhnya terhadap sifat fungsional kekuatan gel. Gelatin dengan berat molekul besar $(>100 \mathrm{kD})$ mengandung jumlah sub unit $\alpha$ yang lebih banyak dan menghasilkan sifat fungsional kekuatan gel yang lebih besar (Eysturskaro, Haug, Elharfaoui, Djabourov, \& Draget, 2012) serta aktivitas dan stabilitas emulsi yang tinggi (Ahmad \& Benjakul, 2011). Sub unit $\alpha 1$ dan $\alpha 2$ dalam molekul gelatin kulit ikan tilapia juga dapat dipisahkan dengan ultrafiltrasi menggunakan membran selulosa MWCO 100 kD. Sub unit a1 ditunjukkan pada berat molekul $110 \mathrm{kD}$, sedangkan sub unit a2 pada berat molekul $200 \mathrm{kD}$ dengan kandungan asam amino terbesar glisin (Chen et. al., 2015). Sub unit $\alpha$ terdiri dari $\alpha_{1}$ dan $\alpha_{2}$ dimana rantai $\alpha_{1}$ mengandung sedikit asam amino histidin, tirosin, lisin, banyak mengandung hidroksiprolin dan asam amino lipofilik lainnya seperti valin, leusin dan isoleusin dari pada sub unit $\alpha_{2}$ (Ward \& Court, 1977). Kandungan asam amino dalam sub unit $\alpha$ dengan rasio yang berbeda menyebabkan molekul gelatin memiliki banyak muatan ionik, yang dapat menghasilkan sifat fungsional gelatin yang berbeda pula.

\section{Gugus Fungsional}

Gugus fungsional molekul fraksi gelatin kulit ikan nila (O. niloticus) dari proses asam asetat $0,10 \mathrm{M}$ selama 2 jam (GAs) dan asam sitrat 0,05 M selama 1 jam (GSi) dapat dilihat pada Gambar 3. Gambar 3 menunjukkan spektra FTIR fraksi molekul GAs dan

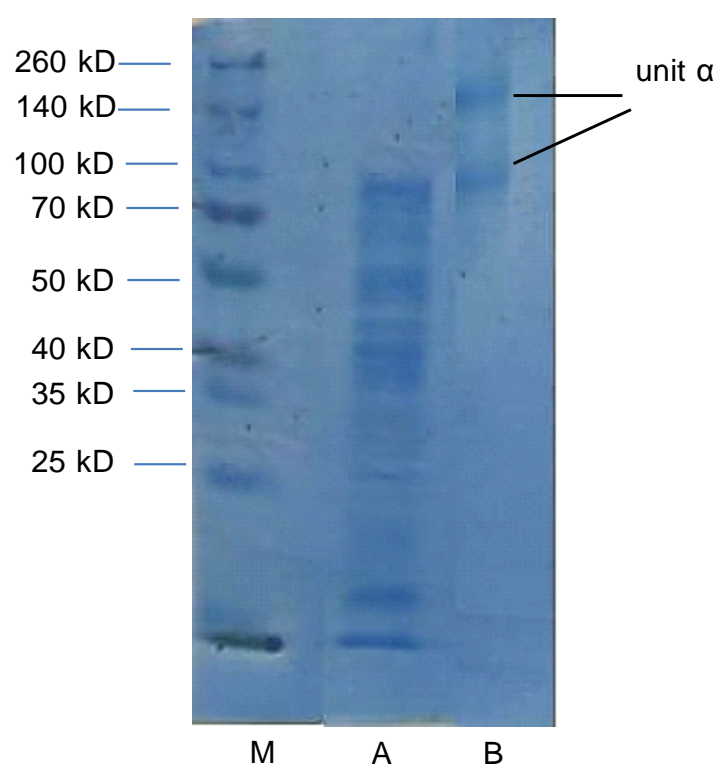

Gambar 2. Distribusi berat molekul fraksi gelatin kulit ikan nila (O. niloticus) dari asam sitrat $0,05 \mathrm{M}$ selama 1 jam (GSi). M : Marker protein, C : fraksi retentate $100 \mathrm{kD}, \mathrm{D}$ : fraksi permeate $100 \mathrm{kD}$.

Figure 2. Molecular weight distribution of gelatin tilapia fish (‥ niloticus) skin fraction from $0.05 \mathrm{M}$ citric acid processed for 1 hour. $M$ : protein marker, $C$ : retentate $100 \mathrm{kD}$ fraction, $D$ : permeate 100 $k D$ fraction. 


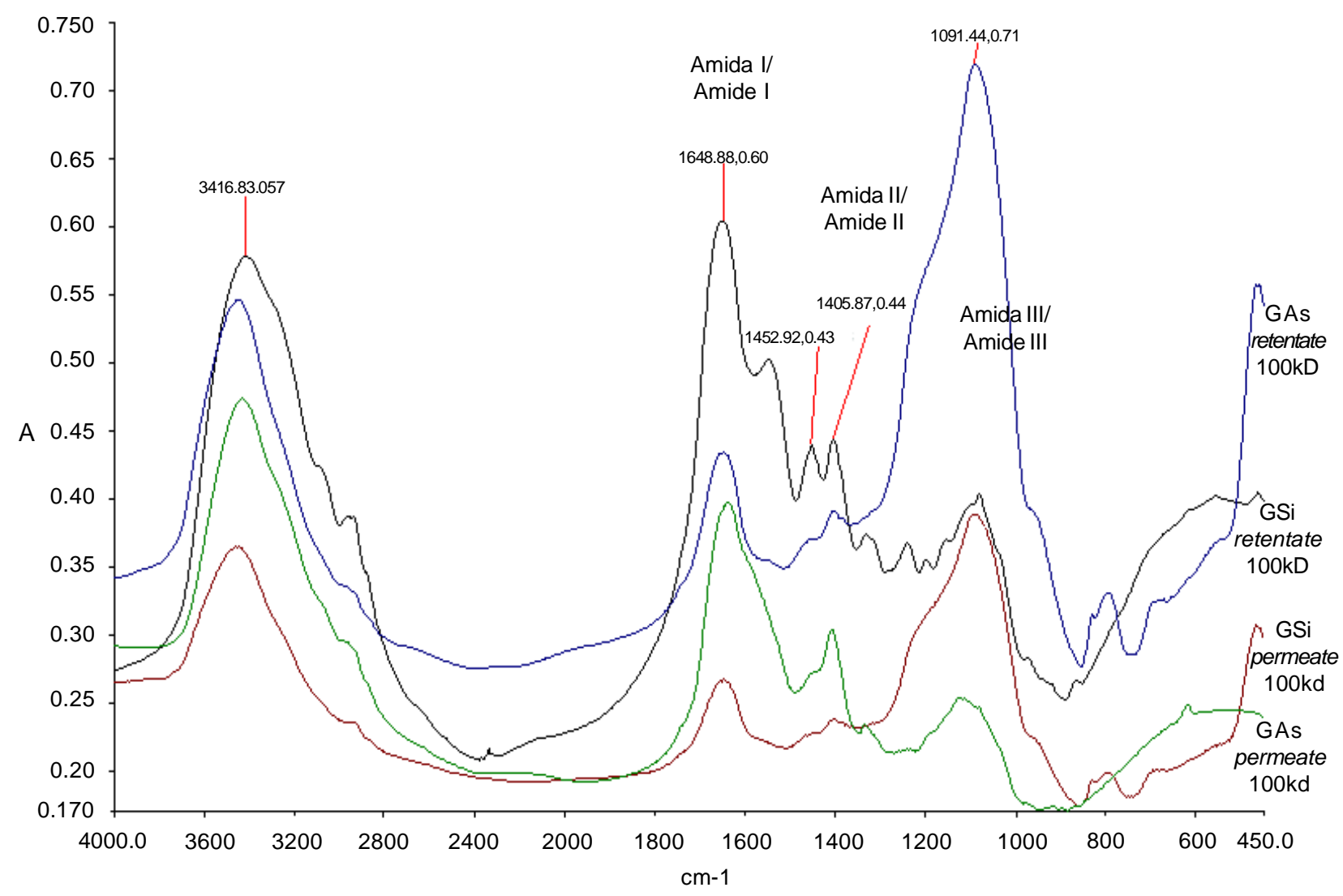

Gambar 3. Spektra FTIR fraksi gelatin kulit ikan nila (O. niloticus) dari proses asam asetat $0,10 \mathrm{M}$ selama 2 jam (GAs) dan asam sitrat 0,05 M selama 1 jam (GSi).

Figure 3. FTIR spectra of gelatin tilapia fish (‥ niloticus) skin fraction from $0.10 \mathrm{M}$ acetat acid processed for 2 hours (GAs) and $0.05 \mathrm{M}$ citric acid processed for 1 hour (GSi).

GSi masing-masing yaitu fraksi retentate $100 \mathrm{kD}$ dan fraksi permeate $100 \mathrm{kD}$. Keempat fraksi tersebut memiliki puncak spektra FTIR yang hampir sama yaitu pada area amida I $\left(1648 \mathrm{~cm}^{-1}\right)$ dan amida II $\left(1452 \mathrm{~cm}^{-}\right.$ $\left.{ }^{1}\right)$ dengan puncak tertinggi pada fraksi GSi retentate $100 \mathrm{kD}$ dan terendah pada fraksi GAs permeate $100 \mathrm{kD}$. Area amida I menunjukkan adanya peregangan ikatan rantai ganda $(\mathrm{C}=\mathrm{O})$ karena adanya peregangan $\mathrm{C}$ $\mathrm{N}$. Area amida II menunjukkan kombinasi peregangan $\mathrm{C}-\mathrm{N}$ dan $\mathrm{N}-\mathrm{H}$ dalam polipeptida. Area amida I dan II tersebut menunjukkan terdapatnya gugus fungsi yang khas rantai a helix dalam molekul gelatin yang dihasilkan dari proses hidrolisis molekul kolagen triple helix (Ahmad \& Benjakul, 2011).

Proses ekstraksi gelatin pada suhu tinggi yang dilanjutkan dengan faksinasi dan pemekatan pada suhu $40{ }^{\circ} \mathrm{C}$ dapat melepas ikatan kovalen dalam gugus molekul gelatin sehingga ditemukan gugus polipeptida gelatin pada spektra FTIR. Hal ini diketahui dari Gambar 3 juga terdapat puncak tertinggi pada spektra $1089 \mathrm{~cm}^{-1}$ pada fraksi GAs retentate 100kd dan terendah pada fraksi GAs permeate 100kd yang menunjukkan terdapatnya potongan rantai $\alpha$ helix berupa polipeptida yang diperoleh dari proses fraksinasi dengan membran dialisis. Spektra FTIR pada bilangan gelombang $1240-670 \mathrm{~cm}^{-1}$ merupakan area amida III yang menujukkan adanya vibrasi peregangan $\mathrm{C}-\mathrm{N}$ dan $\mathrm{N}-\mathrm{H}$ yang ditimbulkan dari peregangan $\mathrm{CH}_{2}$ dari gugus fungsi glisin dan prolin (Zarai, Balti, Mejdouba, Gargouri, \& Sayari, 2012). Amida III pada spektra 1144-985 $\mathrm{cm}^{-1}$ menunjukkan peregangan C-O dari rantai peptida (Ahmad \& Benjakul. 2011), yang mengindikasikan bahwa molekul kolagen triple helix telah hilang selama proses pra-perlakuan dan ekstraksi gelatin (Kaewruang, Benjakul, \& Prodpran 2013).

\section{Sifat Emulsi}

Nilai Emulsion Activity Index (EAl) dan Emulsion Stability Index (ESI) gelatin GAs dan GSi native 
beserta fraksinya pada konsentrasi $0,1 \%$ dapat dilihat pada Gambar 4. Secara umum, nilai EAI dan ESI gelatin GAs native dengan fraksinya lebih besar daripada GSi native nya dengan fraksinya. Nilai EAI tertinggi pada GAs native sebesar $4,83 \mathrm{~m}^{2} / \mathrm{g}$ dan terendah pada fraksi GSi permeate 100kd yaitu 2,20 $\mathrm{m}^{2} / \mathrm{g}$ sedangkan ESI tertinggi pada GAs native yaitu 22,52 menit, dan terendah pada fraksi GSi retentate $100 \mathrm{kd}$ yaitu 13,20 menit.

Selain itu, gelatin GAs dan GSi native tanpa proses fraksinasi memiliki aktifitas emulsi (EAl) dan stabilitas emulsi (ESI) paling tinggi daripada fraksinya (retentate $100 \mathrm{kD}$ dan permeate $100 \mathrm{kD}$ ). EAl gelatin GAs native $\left(4,83 \mathrm{~m}^{2} / \mathrm{g}\right)$ dan ESI (22,52 menit) lebih besar daripada EAI GSi native $\left(4,27 \mathrm{~m}^{2} / \mathrm{g}\right)$ dan ESI (21,87 menit). Namun hasil analisis sifat emulsi tersebut menunjukkan molekul gelatin GAs dan GSi native menghasilkan aktifitas emulsi yang tidak berbeda selama proses pembentukan emulsi $(p>0.05)$, sedangkan pada fraksi gelatin GAs dan GSi retentate $100 \mathrm{kD}$ memiliki aktifitas dan stabilitas emulsi lebih besar daripada permeate $100 \mathrm{kD}(\mathrm{p}<0.05)$.

Aktivitas emulsi dari fraksi gelatin dari kulit ikan nila (Gambar 4) lebih rendah daripada gelatin dari kulit ikan Unicorn leatherjacket (Aluterus monoceros) sebesar $15,16-39,17 \mathrm{~m}^{2} / \mathrm{g}$ pada konsentrasi $1-3 \%$, sedangkan stabilitas emulsinya lebih tinggi (Ahmad \& Benjakul, 2011). Stabilitas emulsi fraksi gelatin kulit ikan nila (Gambar 4) juga tidak jauh berbeda dengan gelatin dari kulit ikan zebra blenny (Salaria basilisca) yang tertinggi 19,7 menit pada konsentrasi 0,5\% (Ktari et al., 2014).

Gambar 4 juga menunjukkan berat molekul gelatin berpengaruh pada sifat emulsi. Hal ini diketahui dari fraksi gelatin GAs dan GSi retentate 100 kD menghasilkan aktivitas dan stabilitas emulsi yang tinggi hampir menyamai bentuk nativenya, sedangkan fraksi permeate $100 \mathrm{kD}$ menghasilkan nilai terendah.
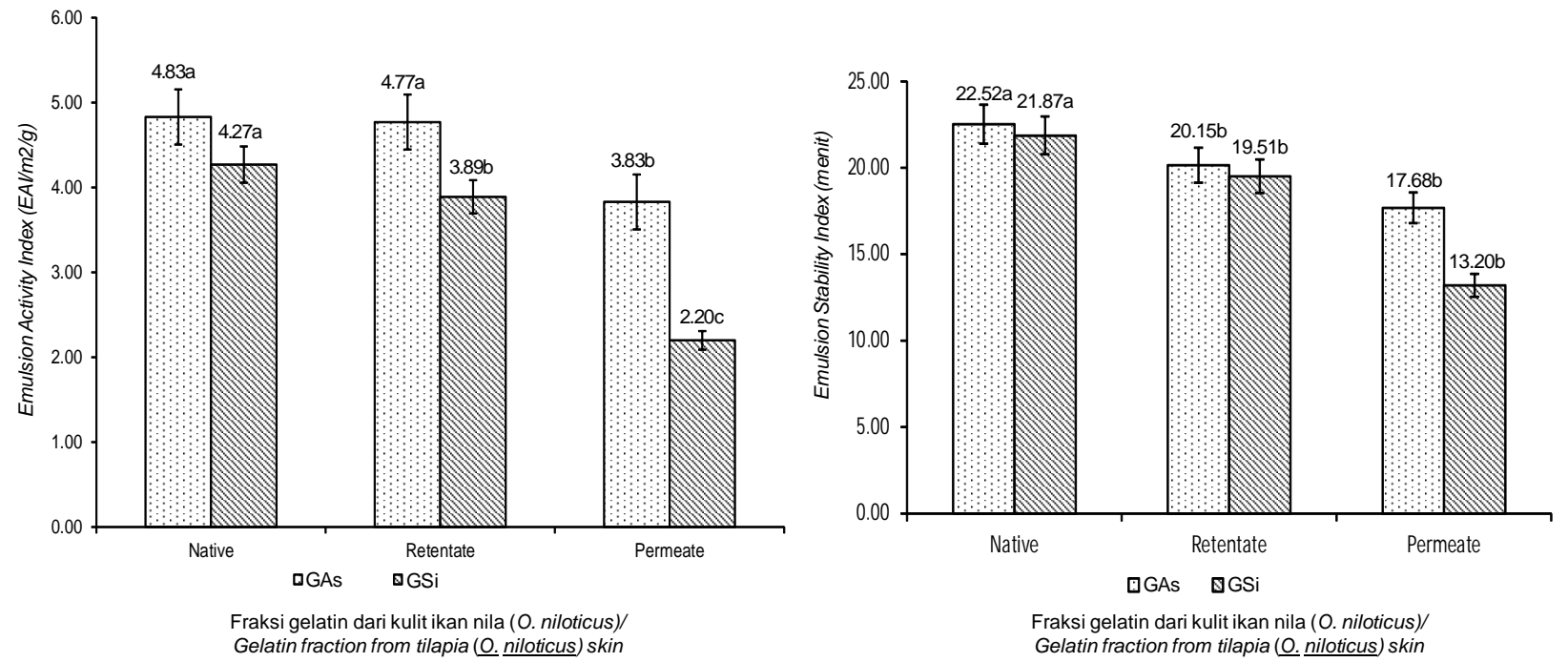

Keterangan / note :

Native/Native = Gelatin native dari kulit ikan nila (O. niloticus)/Native gelatin from tilapia fish (ㅇ. niloticus) skin

Retentate $100 \mathrm{kD}=$ Fraksi gelatin dari kulit ikan nila (O. niloticus) yang tertahan dalam kantong dialisis MWCO $100 \mathrm{kD} /$ Gelatin extract fraction from tilapia fish (‥ niloticus) skin in dialysis bag MWCO 100 $k D$

Permeate $100 \mathrm{kD}=$ Fraksi ekstrak gelatin dari kulit ikan nila (O. niloticus) yang keluar dari kantong dialisis MWCO $100 \mathrm{kD} /$ Gelatin extract fraction from tilapia fish (‥ niloticus) skin which out from dialysis bag MWCO $100 \mathrm{kD}$

Gambar 4. Emulsion Activity Index (EAI) dan Emulsion Stability Index (ESI) fraksi gelatin kulit ikan nila (O. niloticus) dari proses asam asetat $0,10 \mathrm{M}$ selama 2 jam (GAs) dan asam sitrat 0,05 $\mathrm{M}$ selama 1 jam (GSi).

Figure 4. Emulsion Activity Index (EAI) dan Emulsion Stability Index (ESI) of gelatin tilapia fish (․ㅡ. niloticus) skin fraction from $0.10 \mathrm{M}$ acetat acid processed for 2 hours (GAs) and $0.05 \mathrm{M}$ citric acid processed for 1 hour (GSi). 
Fraksi gelatin GAs dan GSi retentate 100 kD memiliki distribusi berat molekul yang lebih besar mengandung sub unit $\alpha$ lebih banyak daripada fraksi permeate 100 kD. Fraksi gelatin GAs dan GSi permeate $100 \mathrm{kD}$ memiliki berat molekul $<100 \mathrm{kD}$ (Gambar 1 dan 2) tidak ditemukan sub unit $\alpha$. Gelatin yang masih dalam kondisi murni (native) mengandung beberapa untaian sub unit $\alpha$ dalam bentuk folding. Perlakuan suhu 40 ${ }^{\circ} \mathrm{C}$ selama proses fraksinasi dan pemekatan dialisat menyebabkan ikatan kovalen diantara sub unit $\alpha$ dalam molekul gelatin dapat terlepas. Hal ini menyebabkan struktur molekul gelatin a helix dalam bentuk folding terpecah menjadi unfolding (Ward \& Corts, 1977). Molekul gelatin dengan sub unit $\alpha$ helix yang panjang dan lebih banyak bersifat non polar dapat membentuk lapisan membran antarmuka droplet emulsi yang lebih tebal dan kuat sehingga emulsi menjadi lebih stabil (Kaewruang et al., 2013).

Struktur molekul protein dalam bentuk unfolding berpengaruh pada sifat hidrofobisitas dan ikatan kovalennya sehingga dapat menyebabkan lebih mudah terlarut dalam larutan fase air. Selain itu daya elektrostatiknya juga menjadi lebih rendah karena muatan ionik molekulnya menjadi berkurang (Dickines, 2017). Hal ini terlihat pada fraksi GAs dan GSi permeate $100 \mathrm{kD}$ yang menunjukkan kestabilan emulsi yang rendah. Kestabilitas emulsi juga dipengaruhi oleh kekuatan daya tarik menarik elektrostatik antar muatan ionik dalam molekul gelatin yang terserap pada lapisan antarmuka (interface). Gelatin dengan berat molekul rendah dengan kandungan sub unit a lebih sedikit atau tidak terdapat sub unit $\alpha$ tidak banyak mengandung asam amino. Hal ini menyebabkan kestabilan emulsi menjadi rendah karena kurang adanya muatan ionik pada lapisan antarmuka fase air dan minyak.

\section{Ukuran Partikel Emulsi dan Mikrostruktur Emulsi}

Ukuran partikel emulsi ditunjukkan dengan nilai rata-rata diameter droplet emulsi yang dihasilkan. Rata-rata diameter droplet emulsi dari gelatin GAs dan GSi native beserta masing-masing fraksinya pada konsentrasi $0,1 \%$ pada Gambar 5, dengan pengamatan visual emulsinya menggunakan optic microscope disajikan pada Gambar 6.

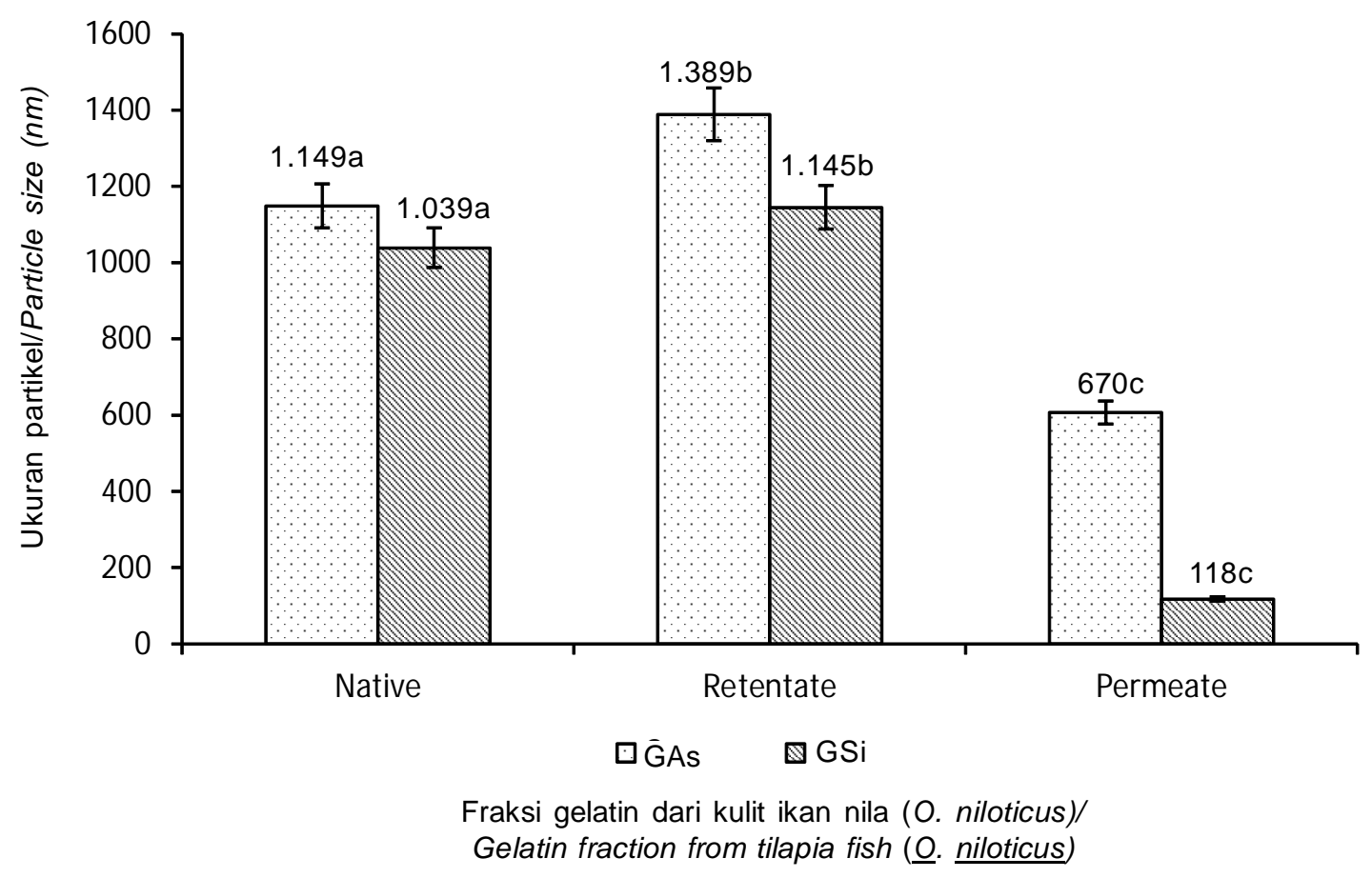

Gambar 5. Ukuran partikel emulsi gelatin GAs native dan GSi native dengan fraksi retentate $100 \mathrm{kd}$ dan permeate $100 \mathrm{kD}$

Figure 5. Particle size emulsion of gelatin Gas native and GSi native with fraction of retentate $100 \mathrm{kD}$ dan permeate $100 \mathrm{kD}$ 


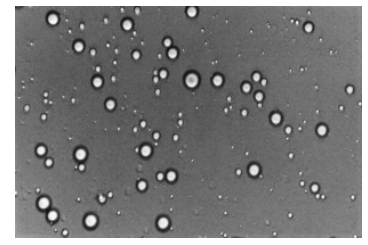

GAs native

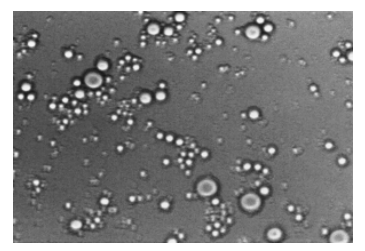

GSi native

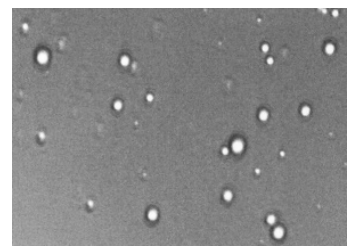

GAs retentate $100 \mathrm{kD}$

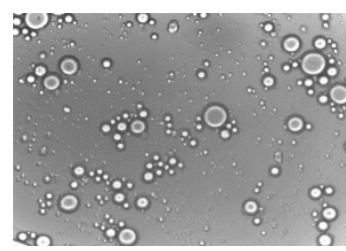

GSi retentate $100 \mathrm{kD}$

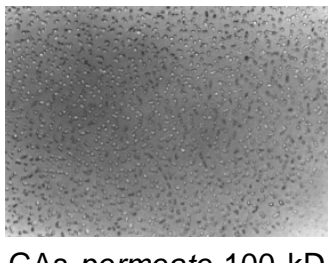

GAs permeate $100 \mathrm{kD}$

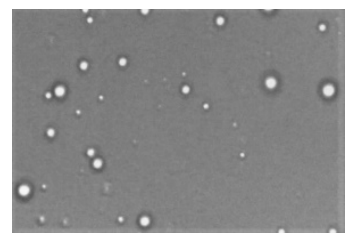

GSi permeate $100 \mathrm{kD}$

Gambar 6. Pengamatan visual emulsi GAs native dan GSi native dan fraksi retentate $100 \mathrm{kD}$ dan permeate $100 \mathrm{kD}$

Figure 6. Visual observation of gelatin Gas native and GSi native with fraction of retentate $100 \mathrm{kD}$ and permeate $100 \mathrm{kD}$

Berat molekul gelatin GAs dan GSi native beserta masing-masing fraksinya berpengaruh nyata pada ukuran partikel emulsi yang dihasilkan $(p<0.05)$. Berdasarkan Gambar 5 diketahui fraksi GAs retentate $100 \mathrm{kD}$ memiliki ukuran rata-rata diameter droplet yang paling besar (1389 nm) dan yang paling rendah fraksi GSi permeate $(118 \mathrm{~nm}) 100 \mathrm{kD}(118 \mathrm{~nm})$.

Ukuran droplet emulsi GAs native dan GSi native lebih rendah daripada fraksi GAs dan GSi retentate $100 \mathrm{kD}$ sedangkan pada fraksi GAs dan GSi permeate $100 \mathrm{kD}$ tidak banyak terbentuk emulsi karena kurang adanya muatan ion dalam molekul gelatin yang terserap pada permukaan droplet. Hal ini menunjukkan berat molekul gelatin dengan kandungan sub unit $\alpha$ dapat mempengaruhi dalam pembentukan emulsi. Berat molekul gelatin yang rendah mengandung sub unit $\alpha$ yang terdiri dari asam amino yang lebih rendah sehingga muatan ion pada lapisan antar muka (interface) droplet emulsi menjadi sedikit. Hal ini menyebabkan aktifitas pembentukan emulsi yang terbentuk dari gelatin dengan berat molekul rendah menjadi lebih sedikit dan pembentukan emulsi menjadi kurang stabil (Gambar 4).

Berdasarkan Gambar 6 dapat diketahui ukuran droplet emulsi dari $0,1 \%$ GAs native $(1149 \mathrm{~nm})$ dan GSi native $(1039 \mathrm{~nm})$ beserta fraksi retentate $100 \mathrm{kD}$ (1389 nm dan $1145 \mathrm{~nm}$ ) dan permeate $100 \mathrm{kD}$ (670 $\mathrm{nm}$ dan $118 \mathrm{~nm}$ ), sehingga emulsi tersebut termasuk dalam makroemulsi. Makroemulsi memiliki ukuran droplet berkisar antara 0,1-100ìm, sedangkan mikroemulsi 10-100 nm (Bouyer, Mekhloufi, Rosilio,
Grossiord, \& Agnely, 2012). Ukuran droplet emulsi gelatin GAs dan GSi beserta fraksinya tersebut lebih besar daripada ukuran droplet emulsi dari gelatin ikan tipe A dengan berat molekul $\approx 55 \mathrm{kD}$ dan $\approx 120 \mathrm{kD}$. Surh et.al., (2006) menyatakan ukuran rata-rata diameter droplet emulsi dari gelatin ikan tipe A dengan berat molekul $\approx 55 \mathrm{kD}$ dan $\approx 120 \mathrm{kD}$ sebesar $\approx 0.35$ ìm dan $\approx 0.71 \mu \mathrm{m}$. Namun demikian, emulsi yang terbentuk dari gelatin GAs dan GSi native beserta fraksinya tersebut diatas memiliki stabilitas emulsi yang tinggi mencapai 22,62 menit pada konsentrasi $0,1 \%$ (Gambar 4) dengan ukuran partikel drioplet > $200 \mathrm{~nm}$ (Gambar 5), kecuali pada fraksi GSi permeate 100 kD. Tavernier et al. (2016) menyatakan ukuran partikel emulsi gelatin $\approx 200 \mathrm{~nm}$ menunjukkan stabilitas emulsi yang tinggi pada kondisi $\mathrm{pH}$ yang jauh dari titik isoelektrik sehingga dapat mencegah terjadinya coalescence. Karakteristik emulsi tersebut juga menunjukkan bahwa fraksi gelatin GAs dan GSi dapat diaplikasikan pada produk pangan emulsi minyak dalam air seperti ice cream, whipping cream dan salad dressing (Hasenhuettl dan Hartel, 2008).

\section{pH Emulsi}

Nilai pH emulsi dari GAs native dan GSi native beserta fraksinya dapat dilihat pada Tabel 2. Dari Tabel 2 diketahui nilai $\mathrm{pH}$ fraksi GAs native dan GSi native dengan fraksi retentate $100 \mathrm{kD}$ memiliki nilai $\mathrm{pH}$ yang lebih rendah daripada fraksi permeate $100 \mathrm{kD}$.

Nilai $\mathrm{pH}$ emulsi gelatin yang terbentuk dipengaruhi oleh $\mathrm{pH}$ gelatin yang digunakan. Gelatin kulit ikan nila 
Tabel 1. Nilai pH emulsi gelatin GAs native dan GSi native dengan fraksi retentate $100 \mathrm{kD}$ dan retentate fraksi permeate $100 \mathrm{kD}$

Table 1. $\mathrm{pH}$ value of gelatin Gas native and GSi native with fraction of retentate $100 \mathrm{kD}$ and permeate 100 $k D$

\begin{tabular}{lc}
\hline \multicolumn{1}{c}{ Sampel/Sample } & $\mathbf{p H} / \mathbf{p H}$ \\
\hline GAs native & $5.50 \pm 0.10^{\mathrm{a}}$ \\
GAs retentate $100 \mathrm{kD}$ & $5.54 \pm 0.06^{\mathrm{a}}$ \\
GAs permeate $100 \mathrm{kD}$ & $6.44 \pm 0.16^{\mathrm{b}}$ \\
GSi native & $4.03 \pm 0.04^{\mathrm{a}}$ \\
GSi retentate $100 \mathrm{kD}$ & $3.98 \pm 0.04^{\mathrm{a}}$ \\
GSi permeate $100 \mathrm{kD}$ & $4.83 \pm 0.04^{\mathrm{b}}$ \\
\hline
\end{tabular}

yang diisolasi dari proses asam sitrat $0.05 \mathrm{M}$ selama 1 jam (GSi) memiliki nilai $\mathrm{pH}$ yang lebih rendah daripada proses asam asetat $0.10 \mathrm{M}$ selama 2 jam (GAs). Asam sitrat memiliki daya ionisasi yang lebih besar daripada asam asetat karena memiliki tiga gugus asam karboksilat (Niu et al., 2013). Selain itu, hasil pengamatan visual emulsi dengan alat foto mikroskop optic (Gambar 6) menunjukkan emulsi dari gelatin GAs dan GSi native memiliki distribusi ukuran droplet yang lebih homogen daripada fraksi retentate $100 \mathrm{kD}$ dan permeate $100 \mathrm{kD}$. Pada fraksi GAs dan
GSi permeate $100 \mathrm{kD}$ tidak terlihat adanya droplet emulsi yang seragam bentuknya. Hal ini disebabkan kurang adanya daya tarik ionik dalam larutan gelatin dengan berat molekul rendah pada konsentrasi yang rendah. Nilai $\mathrm{pH}$ fraksi GAs permeate $100 \mathrm{kD}$ sebesar 6,44 paling besar diantara nilai $\mathrm{pH}$ dari fraksi lainnya. Kelarutan protein akan menurun pada nilai $\mathrm{pH}$ yang mendekati nilai titik isoelektrik, dimana nilai titik isoelektrik gelatin GAs dan GSi berada pada pH 8,5 (Suryanti et al., 2016).

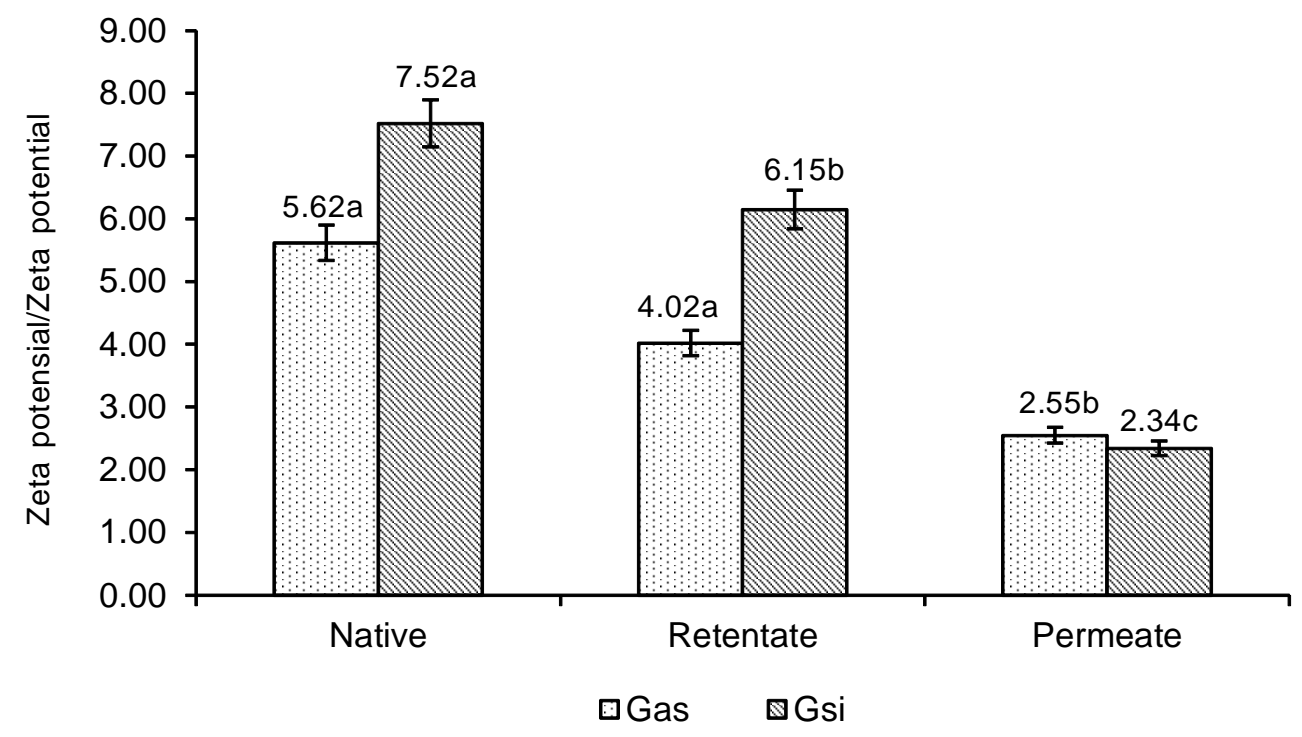

Fraksi gelatin dari kulit ikan nila (O. niloticus)/

Gelatin fraction from tilapia fish (ㅇ. niloticus) skin

Gambar 7. Zeta potensial emulsi gelatin GAs dan GSi nativedan fraksi retentate $100 \mathrm{kD}$ dan permeate $100 \mathrm{kD}$.

Figure 7. Zeta potensial of gelatin Gas native and GSi native with fraction of retentate $100 \mathrm{kD}$ and permeate $100 \mathrm{kD}$. 


\section{Zeta Potensial}

Zeta potensial adalah besarnya muatan elektron pada permukaan droplet partikel dalam suatu sistem emulsi. Zeta potensial sangat erat berkaitan dengan nilai $\mathrm{pH}$ emulsi dan titik isoelektrik gelatin yang digunakan dalam pembentukan emulsi. Semakin jauh nilai $\mathrm{pH}$ emulsi gelatin yang terbentuk dari titik isoelektrinya, maka semakin besar muatan elektron pada permukaan droplet partikel emulsi. Hal ini menunjukkan pembentukan emulsi yang stabil karena terjadi interaksi antara muatan ion gelatin dalam air fase air dan minyak dalam sistem emulsi.

Nilai zeta potensial emulsi yang terbentuk dari GAS native dan GSi native beserta fraksinya yaitu fraksi retentate $100 \mathrm{kD}$ dan permeate $100 \mathrm{kD}$ dapat dilihat pada Gambar 7. Pada gambar ini terlihat nilai zeta potensial pada gelatin GAs native dan GSi native beserta fraksi retentate $100 \mathrm{kD}$ dan permeate 100 $\mathrm{kD}$ bernilai positif. Zeta potensial tertinggi pada gelatin GSi native yaitu $+7,52$ sedangkan nilai zeta potensial terendah pada fraksi GSi permeate $100 \mathrm{kD}$ sebesar + 2,34 yang tidak berbeda jauh dengan fraksi GAs permeate $100 \mathrm{kD}+2,55$.

Nilai zeta potensial yang rendah menyebabkan kestabilan emulsi menjadi rendah karena daya tarik antar muatan ion dalam molekul gelatin dengan fase minyak dan air rendah yang dapat menyebabkan rendahnya kemampuan dalam pembentukan droplet emulsi (Gambar 5). Selain itu, gelatin GSi native beserta fraksi retentate $100 \mathrm{kD}$ dan permeate $100 \mathrm{kD}$ lebih banyak bermuatan positif daripada GAs native dan fraksinya. Asam sitrat memiliki beberapa grup molekul terionisasi yang reaktif terdiri dari tiga grup karboksilat $\left(\mathrm{pK}_{\mathrm{a} 1}=3,13 ; \mathrm{pK}_{\mathrm{a} 2}=4,76 ; \mathrm{pK}_{\mathrm{a} 3}=6,39\right)$ dan satu grup $\mathrm{OH}$ (Vancik, 2014), sehingga dapat memecah struktur molekul kolagen triple helix lebih banyak (Niu et al., 2013) dan dapat menghasilkan molekul gelatin dengan muatan positif yang lebih banyak.

\section{KESIMPULAN}

Fraksinasi gelatin dari kulit ikan nila (Oreochromis niloticus) yang diperoleh dari proses asam asetat 0,10 $M$ dan asam sitrat $0,05 \mathrm{M}$ dengan menggunakan kantong dialisis MWCO $100 \mathrm{kD}$ dapat diperoleh fraksi distribusi berat molekul 13,6-218,87 kD dan 15,27$61,1 \mathrm{kD}$ (dari proses asam asetat) dan 107,5-142,23 kD dan 12,5-82,9 kD (dari proses asam sitrat). Gugus fungsional molekul dari keempat fraksi gelatin tersebut terdiri dari amida I $\left(1648 \mathrm{~cm}^{-1}\right)$, amida II $\left(1452 \mathrm{~cm}^{-1}\right)$ dan amida III $\left(1089 \mathrm{~cm}^{-1}\right)$. Karakteristik emulsi yang meliputi sifat emulsi (aktifitas dan stabilitas emulsi) semakin meningkat dengan semakin meningkatnya berat molekul. Nilai zeta potensial droplet emulsi dari fraksi gelatin kulit ikan nila dan nativenya bermuatan positif, dimana gelatin kulit ikan nila dari proses asam sitrat lebih banyak bermuatan ion positif daripada proses asam asetat. Emulsi yang terbentuk dari fraksi GAs dan GSi pada konsentrasi 0,1\% memiliki ukuran droplet $>100 \mathrm{~nm}$ sehingga termasuk dalam makroemulsi. Makroemulsi dari fraksi GAs dan GSi memiliki stabilitas yang tinggi mencapai 22,62 menit sehingga dapat diaplikasikan pada produk pangan seperti ice cream, whipping cream dan salad dressing.

\section{DAFTAR PUSTAKA}

Ahmad, M. \& Benjakul, S. (2011). Characteristics of gelatin from the skin of unicorn leatherjacket (Aluterus monoceros)asinfluenced by acid pretreatment and extraction time. Food Hydrocolloids, 25, 381-388. doi:10.1016/j.foodhyd.2010.07.004.

Anonim. (2012). GMIA. Gelatin Handbook. Gelatin Manufacture Institute of America. Amerika.

Bouyer, E., Mekhloufi, G., Rosilio, V., Grossiord, J. L., \& Agnely, F. (2012). Proteins, polysaccharides, and their complexes used as stabilizers for emulsions: Alternatives to synthetic surfactants in the pharmaceutical field. International Journal of Pharmaceutics, 436, 359-378.

Biorad Laboratories. (2016). A guide to Polyacrylamide Gel Electrophoresis and Detection. California. USA. Life Science Group. Retrieved from http://www.biorad.com/webroot/web/pdf/lsr/literature/ Bulletin_6040.

Chen, S., Tang, L., Su, W., Weng, W., Osako, K., \& Tanaka, M. (2015). Separation and characterization of alphachain subunits from tilapia (Tilapia zillii) skin gelatin using ultraviltration. Food Chemistry, 188, (35035 ) $6 . \mathrm{h} \mathrm{t} \mathrm{t} \mathrm{p://dx.doi.org/10.1016/}$ j.foodchem.2015.04.084.

Dickines, E. 2017. Biopolymer-based particles as stabilizing agents for emulsions and Foams. Food Hydrocolloids, 68, 219-231.

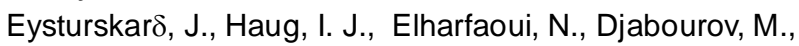
\& Draget, K. I. (2012). Structural and mechanical properties of ûsh gelatin as a function of extraction conditions. Food Hydrocolloids, 23, 1702-1711. doi:10.1016/j.foodhyd.2009.01.008.

Gao, Z., Zhao, J., Huang, Y., Yao, X.. Zhang, K., Fang, Y., Nishinari, K. Phillips, G.. Jiang, F. \& Yang, H. (2017). Edible Pickering emulsion stabilized by proteinfibrils. Part 1: Effects of $\mathrm{pH}$ and fibrils concentration. LWT Food Science and Technology, 76, 1-8. http:// dx.doi.org/10.1016/j.Iwt.2016.10.038.

Hattrem, M. N., Molnes, S., Haug, I.J. \& Draget, K.J. (2015). Interfacial and rheological properties of gelatin based solid emulsions prepared with acid or alkali pretreated gelatins. Food Hydrocolloids, 43 , 700-707. doi:10.1016/j.foodhyd.2010.08.007.

Hasenhuetl, G. L., \& Hartel, R. W. (2008). Food emulsifier and their application. Springer Science. 
Kaewruang, P., Benjakul, S., \& Prodpran, T. (2013). Molecular and functional properties of gelatin from the skin of unicorn leatherjacket as affected by extracting temperatures. Food Chemistry, 138, 14311437 . h t t p : //d x.doi.org/10.1016/ j.foodchem.2012.09.114.

Ktari, N., Mourad, I., Rim, N., Imen, L., Hanen, B. A., Barkia, A. \& Moncef, N. (2014). Characteristics and functional properties of gelatin from zebra blenny (Salaria basilisca) skin. LWT - Food Science and Technology, 58, 602-608. http://dx.doi.org/10.1016/ j.Iwt.2014.03.036.

Liu, H., Wong, B., Barrow, C.J. \& Adhikari, B. (2014). Relating the variation of secondary structure of gelatin at fish oil-water interface to adsorption kinetics. dynamic interfacial tension and emulsion stability. Food Chemistry, 143, 484-491. http://dx.doi.org/ 10.1016/j.foodchem.2013.07.130.

Mc. Clement D. J. (2005). Food Emulsions. Principles. Practices. and Techniques. Second Edition. CRC Press. Washington DC.

Montoya, M. H. U., Ortega, H. S., Moroyoqui, F. J. C., Sández, O. R., Atomea, M. P. \& Braue, J. M. E. 2011. Giant squid skin gelatin: Chemical composition and biophysical characterization. Food Research International, 44, 3243-3249. doi:10.1016/ j.foodres.2011.08.018.

Mulder, M. 1996. Basic principle of the membrane technology. Kluwer academic publisher. London.
Niu, L., Zhou, X., Yuan, C., Bai, Y., Yang, F. \& Huang, Y. (2013). Characterization of tilapia (Oreochromis niloticus) skin gelatin extracted with alkaline and different acid pretreatments. Food Hydrocolloids, 33 (336-341).http://dx.doi.org/10.1016/ j.foodhyd.2013.04.014.

Pearce, K. N. \& Kinsella, J. E. (1978). Emulsifying Properties of Proteins: Evaluation of a Turbidimetric Technique. Journal of Agric. Food Chem., 26(3), 0021-8561/78/1426-0716\$01 .00/O

Phillip, G. O. \& Williams, P. A. (2009). Handbook of Hydrocolloids. Second edition. CRC Press. Washington. DC.

Surh, J., Decker, E. A., \& McClement, D.J. (2006). Properties and stability of oil-in-water emulsions stabilized by fish gelatin. Food Hydrocolloids, 20 (596606). doi:10.1016/j.foodhyd.2005.06.002

Suryanti, Indrati, R., Irianto, H.E., \& Marseno, D.W. (2016). Comparison Study on the Extraction of Gelatin from Nila Fish (Oreochromis nilotichus) Skin Using Acetic Acid and Citric Acid. Pakistan Journal of Nutrition, 15 (8), 777-783. ISSN 1680-5194.

Ward, A. G. \& Courts, A. (1977). The Science and Technology of Gelatin. Academic Press. London.

Zarai, Z., Balti, R., Mejdouba, H., Gargouri, Y., \& Sayari, A. (2012). Process for extracting gelatin from marine snail (Hexaplex trunculus) : Chemical composition and functional properties. Process Biochemistry, 47,1779-1784.http://dx.doi.org/10.1016/ j.procbio.2012.06.007. 